\title{
Concise Asymmetric Synthesis of Kweichowenol A
}

\author{
David B. Konrada (D) \\ Bilal Kicina \\ Dirk Trauner*a,b (D) \\ ${ }^{a}$ Department of Chemistry, Ludwig-Maximilans University Munich, Butenandt- \\ straße 5-13, 81377 München, Germany \\ ${ }^{b}$ Department of Chemistry, New York University, 100 Washington Square East, \\ Room 712, New York, 10003, USA \\ dirktrauner@nyu.edu \\ Dedicated to E.J. Corey on the Occasion of his $90^{\text {th }}$ Birthday \\ Published as part of the 30 Years SYNLETT - Pearl Anniversary Issue
}
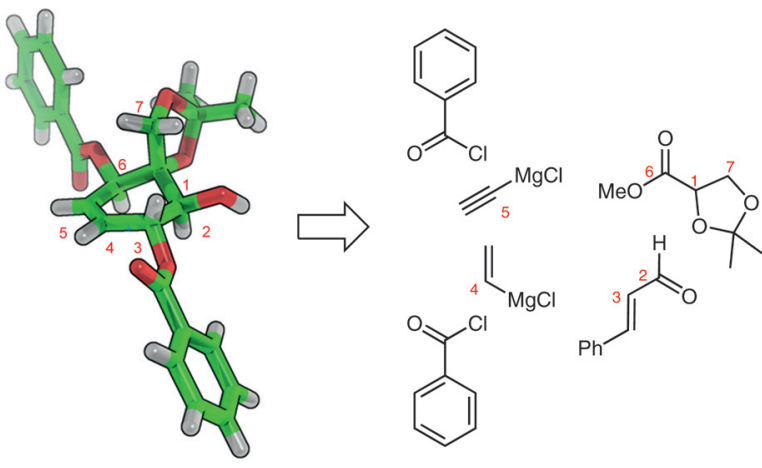

Kweichowenol A
Received: 22.08 .2018
Accepted after revision: 24.10 .2018
Published online: 17.12 .2018
DOI: $10.1055 / s-0037-1610390$; Art ID: st-2018-b0541-I
License terms: CCC

Abstract An asymmetric 11-step synthesis of the polyoxygenated cyclohexene natural product kweichowenol A from the traditional Chinese medicinal herb Uvaria kweichowesis is reported. The oxygenation pattern was installed on a linear precursor by exploiting the acyclic stereocontrol of the Kiyooka aldol reaction, as well as Cram chelate-controlled Grignard reactions. Ring-closing metathesis and a selective benzoylation then gave the natural product.

Key words kweichowenol A, Kiyooka aldol, asymmetric synthesis, natural product synthesis, acyclic stereocontrol

The flowering plants of the Uvaria genus are widely distributed in southern and southwestern China as well as southeastern Asian counties. ${ }^{1}$ Prominent members of this genus are commonly used in traditional Chinese medicine as herbs to treat inflammation and tumors. ${ }^{2}$ For example, the roots and leaves of Uvaria micropara are used to prepare the herb Zi Yu Pan, whereas Uvaria grandiflora is used for the preparation of the herb Shan Jiao $\mathrm{Zi}^{3}{ }^{3}$ This has attracted much attention to their secondary metabolites and it was found that they contain a wealth of polyoxygenated cyclohexenes. $^{4-8}$ Kweichowenol A (1), C (2), and D (3, Scheme 1), for instance, were extracted from Uvaria kweichowesis. They incorporate distinct benzoyl esters at their C3- and C6-positions but differ in their C1- and C7-substitution. ${ }^{7-9}$ Kweichowenol A (1) and C (2) contain unusual acetone- and acetaldehyde-derived spiro 1,3-dioxolane moieties $^{10-14}$ whereas kweichowenol D contains a 1,2-diol. These cyclohexenes share the oxygenation pattern with the kweichowenol-type natural products ferrudiol (4) and ellipeiopsol B (5) which were isolated from Uvaria ferruginea and the closely related Ellipeiopsis cherrevensis, respective- ly. ${ }^{6,9,15}$ Ferrudiol (4) and ellipeiopsol B (5) have shown to inhibit efflux-related antibiotic resistance in Staphylococcus aureus whereas kweichowenol A, C, and D showed antitumor activities against the bronchogenic carcinoma cells A549, SK-MES-1, and NCI-H446. 7,8,16

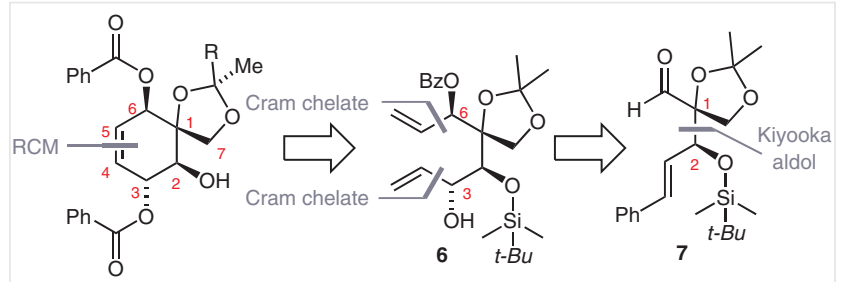

Kweichowenol A (1, R = Me)

Kweichowenol C $(2, R=H)$

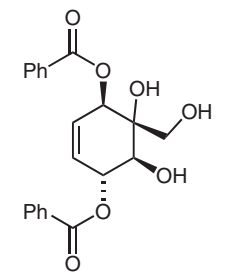

Kweichowenol D (3)

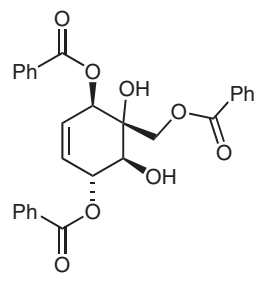

Ferrudiol (4)<smiles>O=C(OC[C@]1(O)[C@@H](O)C=C[C@@H](OC(=O)c2ccccc2)[C@H]1O)c1ccccc1</smiles>

Ellipeiopsol B (5)
Scheme 1 Retrosynthesis of kweichowenol A (1); structures of kweichowenol C (2), D (3), ferrudiol (4), and ellipeiopsol B (5)

We were intrigued by the oxygenation pattern of the kweichowenols, since it is also present in more complex targets such as the members of the tetrodotoxin family of natural products. ${ }^{17,18}$ This prompted us to develop a synthetic approach to the kweichowenols, which is outlined in Scheme 1. Our retrosynthesis focused on kweichowenol A (1), which could serve as a precursor to kweichowenol C (2), D (3), ferrudiol (4), and ellipeiopsol B (5). To enable a rapid, stereoselective construction of the fully functionalized cyclohexene core, we planned to exploit acyclic stereo- 
control and cyclize the resulting linear precursor $\mathbf{6}$ using a ring-closing metathesis (RCM). On this linear precursor $\mathbf{6}$, the $\mathrm{C} 3$ and $\mathrm{C} 6$ stereocenters could be diastereoselectively installed using Grignard additions into the corresponding aldehydes via Cram chelate transition states. ${ }^{19}$ These disconnections led to the aldehyde 7 which could be accessed through a Kiyooka aldol reaction. ${ }^{20}$

Our synthesis of kweichowenol A (1) starts with the preparation of the TBS ketene acetal $\mathbf{9}$ from acetonide ester $\mathbf{8}$ (Scheme 2). The acetonide ester $\mathbf{8}$ could be commercially obtained or synthesized on decagram scale using a 3-step sequence that started from serine and required only one purification step (see Supporting Information).

The Kiyooka aldol reaction is known to proceed with excellent enantioselectivity and diastereoselectivity if disubstituted tert-butyldimethylsilyl (TBS) ketene acetals are used as nucleophiles. ${ }^{21}$ The use of $\mathbf{9}$ as a nucleophile in Kiyooka aldol reactions was pioneered by Kalesse who prepared ent-7 on a small scale. ${ }^{20}$ For the synthesis of kweichowenol A, we devised a modified procedure for the multigram scale synthesis of aldehyde 7 . Our procedure relied on a D-valine-derived oxazaborolidinone reagent $\mathbf{1 0}$ which initiated the asymmetric addition of TBS ketene acetal $\mathbf{9}$ to cinnamaldehyde (11). In contrast to the TMS ketene acetal nucleophiles in Mukaiyama aldol reactions, the use of a TBS-ketene acetal enables the in situ reduction of the latent ester group of $\mathbf{9}$ to the corresponding mixed tert-butyldi- methylsilanol methanol acetal via a hydride transfer from the oxazaborolidinone $\mathbf{1 0}$ to the reaction intermediate. This powerful opening step installed the contiguous C1 and C2 stereocenters (12) in a single transformation. ${ }^{22}$ To liberate the aldehyde functionality 7 , the TBS group could be transferred from the acetal moiety (12) to the C2 alcohol with NaHMDS. By subjecting aldehyde 7 to NMR analysis, we found that the $\mathrm{C} 1$ tertiary alcohol and the $\mathrm{C} 2$ secondary alcohol stereocenters were formed with 5.4:1.0 dr. Thereafter, we determined that the major diastereomer of $\mathbf{7}$ was formed with $85 \%$ ee by using Mosher ester analysis (see Supporting Information). The secondary alcohol at C6 was installed through a diastereoselective addition of ethynylmagnesium chloride to aldehyde $\mathbf{7}$, which presumably proceeded via a 5-membered Cram chelate transition state. ${ }^{19}$ By directly intercepting the magnesium alkoxylate intermediate with benzoyl chloride, alkyne $\mathbf{1 3}$ was obtained in a one-pot sequence with $60 \%$ yield. A successful Upjohn dihydroxylation required the use of citric acid as an additive and was followed by a Lindlar hydrogenation to generate a vinyl group (14). Sodium periodate mediated Criegee oxidation afforded aldehyde $\mathbf{1 5}$. The C3 stereocenter was introduced by a second Cram chelate-controlled addition, in this case of vinylmagnesium chloride, which provided vinyl alcohol 6 in good yield. We subjected the resultant diene $\mathbf{6}$ to a RCM, using the second-generation Hoveyda-Grubbs catalyst (HG-II), and obtained the fully oxygenated cyclohexene 16. It is<smiles>COC(=O)C1COC(C)(C)O1</smiles>

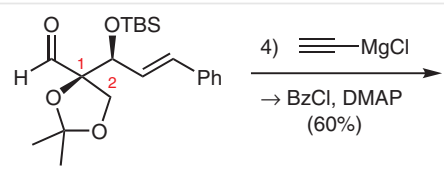
$7(5.4: 1.0 \mathrm{dr}, 85 \%$ ee $)$<smiles>C#C[C@H](OCC)C1([C@H](/C=C/c2ccccc2)C(C)(C)C)COC(C)(C)O1</smiles>

$$
\underset{\text { 6) Lindlar cat., } \mathrm{H}_{2}}{\stackrel{\text { 5) } \mathrm{OsO}_{4}, \mathrm{NMO}}{\text { citric acid }}}
$$<smiles>C=C[C@@H](OC(=O)c1ccccc1)[C@]1([C@H](O)C(O)C(O)c2ccccc2)COC(C)(C)O1</smiles>

14

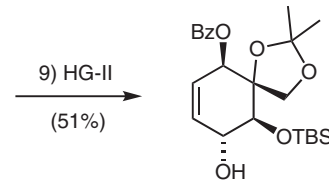

16
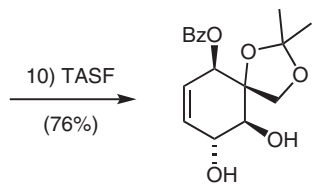

17

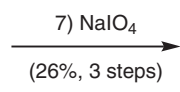

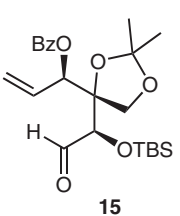

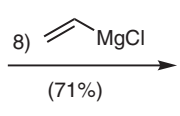<smiles>C=C[C@H](O)[C@@H]([OH2+])[C@]1([C@H](O)C=C)COC(C)(C)O1</smiles>

6
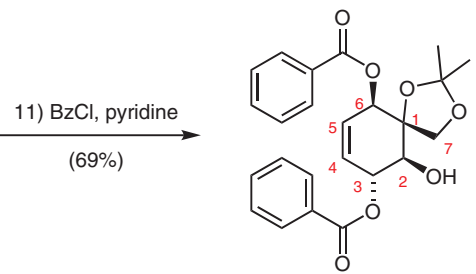

Kweichowenol A (1)

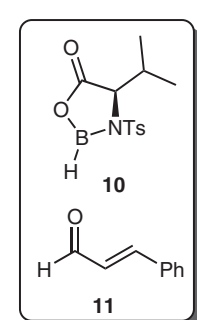

11

Scheme 2 Asymmetric synthesis of kweichowenol A. Reagents and conditions: 1) TBSCl, LiHMDS, THF/HMPA, $-78^{\circ} \mathrm{C} \rightarrow 0{ }^{\circ} \mathrm{C}$, then $\left.8,-78{ }^{\circ} \mathrm{C} ; 2\right) \mathrm{N}$-Ts-Dvaline, $\mathrm{BH}_{3} \cdot \mathrm{THF}, \mathrm{CH}_{2} \mathrm{Cl}_{2}, 0^{\circ} \mathrm{C} \rightarrow \mathrm{rt}$, then $\left.11,9,-78{ }^{\circ} \mathrm{C} ; 3\right) \mathrm{NaHMDS}$, THF, $-78{ }^{\circ} \mathrm{C} \rightarrow 0{ }^{\circ} \mathrm{C}$; 4) ethynylmagnesium chloride, $\mathrm{THF},-78^{\circ} \mathrm{C} \rightarrow 0{ }^{\circ} \mathrm{C}$, then $\mathrm{BzCl}$, DMAP, $0{ }^{\circ} \mathrm{C} \rightarrow \mathrm{rt}$; 5) $\mathrm{OsO}_{4}$, NMO, citric acid, $t$-BuOH/acetone/ $\mathrm{H}_{2} \mathrm{O}, 60^{\circ} \mathrm{C}$; 6) Lindlar cat., $\mathrm{H}_{2}$, EtOAc/pyridine; 7) $\left.\mathrm{NalO}_{4}, \mathrm{THF} / \mathrm{H}_{2} \mathrm{O} ; 8\right)$ vinylmagnesium chloride, THF, $-78^{\circ} \mathrm{C} \rightarrow 0{ }^{\circ} \mathrm{C}$; 9) $\mathrm{HG}-I I$, PhMe, $50{ }^{\circ} \mathrm{C}$; 10) TASF, DMF; 11) BzCl, pyridine, $-27^{\circ} \mathrm{C} \rightarrow-20^{\circ} \mathrm{C}$. DMAP $=4$-(dimethylamino)pyridine, $\mathrm{HG}-\mathrm{II}=$ second-generation Hoveyda-Grubbs catalyst, HMDS = bis(trimethylsilyl)amide, HMPA = hexamethylphosphoramide, NMO = N-methylmorpholine $\mathrm{N}$ oxide, TASF = tris(dimethylamino)sulfonium difluorotrimethylsilicate, TBS = tert-butyldimethylsilyl. 
worth noting, that the free allylic C3 alcohol was essential for a successful RCM reaction and a successful TBS deprotection with tris(dimethylamino)sulfonium difluorotrimethylsilicate (TASF). The resulting diol 17 was regioselectively benzoylated at the sterically more accessible C3 alcohol by using benzoyl chloride in pyridine at low temperatures. These optimized conditions provided kweichowenol A (1) in good yield. ${ }^{23}$ To confirm the structure of the natural product and gain insight into its preferred conformation, we subjected a sample of $\mathbf{1}$ to X-ray analysis (Scheme 3). Remarkably, kweichowenol A (1) crystallized as a racemate from the enantioenriched mixture that was obtained through the synthesis.
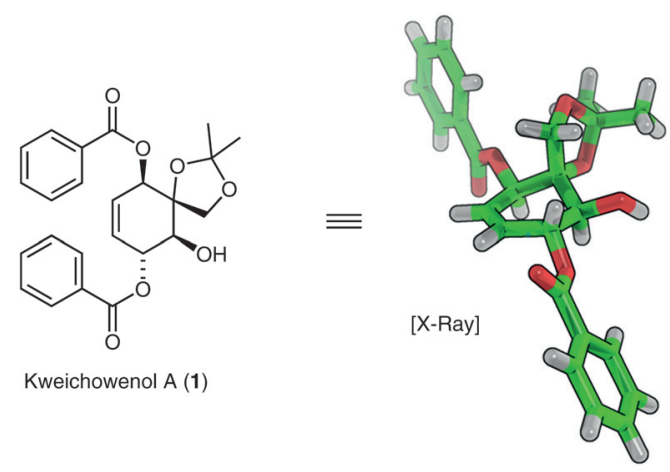

Scheme 3 X-Ray structure of kweichowenol A (1)

In summary, we have devised a short asymmetric synthesis of the polyoxygenated cyclohexene natural product kweichowenol A (1), which proceeds in 11 steps starting from commercially available starting materials. The installation of the oxygenation pattern on a linear precursor allowed a rapid access to the cyclohexene core by exploiting acyclic stereocontrol. Carbon-carbon bonds were formed using a Kiyooka aldol reaction, Cram chelate-controlled Grignard reactions, and a RCM. Due to the common cyclohexene oxygenation pattern, kweichowenol A (1) could serve as a precursor to other members of the kweichowenol-type natural product family, such as kweichowenol C (2), kweichowenol D (3), ferrudiol (4), and ellipeiopsol B (5). It is also worth noting that the $\mathrm{C} 1, \mathrm{C} 2$, and $\mathrm{C} 6$ stereocenters of the kweichowenol-type natural products correspond to the C5, C6, and C7 stereocenters on the cyclohexane core of tetrodotoxin. As such, we have laid the foundation towards an asymmetric synthesis of this celebrated target. ${ }^{17,18,24}$

\section{Acknowledgment}

The authors thank Dr. Peter Mayer for X-Ray analyses. D.B.K is grateful to the Friedrich-Ebert-Stiftung for a PhD scholarship.

\section{Supporting Information}

Supporting information for this article is available online at https://doi.org/10.1055/s-0037-1610390.

\section{References and Notes}

(1) Leboeuf, M.; Cavé, A.; Bhaumik, P. K.; Mukherjee, B.; Mukherjee, R. Phytochemistry 1980, 21, 2783.

(2) Zhou, J.; Xie, G.; Yan, X. In Encyclopedia of Traditional Chinese Medicines, Vol. 3; Springer: Berlin, Heidelberg, 2011.

(3) Xu, J-P. In Cancer Inhibitors from Chinese Natural Medicines; CRC Press: Boca Raton, FL, 2016.

(4) Nkunya, H. H. M.; Weenen, H.; Koyi, J. N.; Thijs, L.; Zwanenburg, B. Phytochemistry 1987, 26, 2563.

(5) Jolad, S. D.; Hoffmann, J. J.; Schram, K. H.; Cole, J. R.; Tempesta, M. S.; Bates, R. B. J. Org. Chem. 1981, 46, 4267.

(6) Schulte, G. R.; Ganem, B.; Chantrapromma, K.; Kodpinid, M.; Kobkull, S. Tetrahedron Lett. 1982, 23, 289.

(7) Xu, Q.-M.; Liu, Y.-L.; Zou, Z.-M.; Yang, S.-L.; Xu, L.-Z. J. Asian Nat. Prod. Res. 2009, 11, 24.

(8) Xu, Q.-M.; Zou, Z.-M.; Xu, L.-Z.; Yang, S.-L. Chem. Pharm. Bull. 2005, 53, 826 .

(9) Kijjoa, A.; Bessa, J.; Pinto, M. M. M.; Anatachoke, C.; Silva, A. M. S.; Eaton, G.; Herz, W. Phytochemistry 2002, 59, 543.

(10) Fang, Y.; Ni, Z.-Y. N.; Yamada, T.; Wang, Y.-F.; Zhang, M.-L.; Dong, M.; Cong, B.; Sauriol, F.; Huo, C.-H.; Shi, Q.-W.; Kiyota, H. Z. Naturforsch., B: J. Chem. Sci. 2010, 65, 1401.

(11) Yu, J. S.; Moon, E.; Choi, S. U.; Kim, K. H. Tetrahedron Lett. 2016, 57, 1699.

(12) Bohman, B.; Tröger, A.; Franke, S.; Lorenzo, M. G. Francke W.; Unelius, C. R. J. Nat. Prod. 2011, 74, 690.

(13) Kim, S. M.; Son, S.; Kim, J. W.; Jeon, E. S.; Ko, S.-K.; Ryoo, I.-J.; Shin, K.-S.; Hirota, H.; Takahashi, S.; Osada, H.; Jang, J.-H.; Ahn, J. S. Nat. Prod. Sci. 2015, 21, 231.

(14) Rodrigues-Heerklotz, K. F.; Drandarov, K.; Heerklotz, J.; Hesse, M.; Werner, C. Helv. Chim. Acta 2001, 84, 3766.

(15) Wirasathien, L.; Pengsuparp, T.; Moriyasu, M.; Kawanishi, K.; Suttisri, R. Arch. Pharm. Res. 2006, 29, 497.

(16) Sun, Z.-L.; He, J.-M.; Wang, S.-Y.; Ma, R.; Khondkar, P.; Kaatz, G. W.; Gibbons, S.; Mu, Q. RSC Adv. 2016, 6, 43518.

(17) Bane, V.; Lehane, M.; Dikshit, M.; Riordan, A.; Furey, A. Toxins 2014, 6, 693.

(18) Goto, T.; Kishi, Y.; Takahashi, S.; Hirata, Y. Tetrahedron 1965, 21, 2059.

(19) Tsubuki, M.; Okita, H.; Honda, T. Heterocycles 2006, 67, 731.

(20) Bülow, L.; Naini, A.; Fohrer, J.; Kalesse, M. Org. Lett. 2011, 13, 6038.

(21) Kiyooka, S.; Kaneko, Y.; Komura, M.; Matsuo, H.; Nakano, M. J. Org. Chem. 1991, 56, 2276.

(22) Kiyooka Aldol Reaction Procedure for the Synthesis of 12 $\mathrm{N}$-Ts-D-valine (SI-1, $7.82 \mathrm{~g}, 28.6 \mathrm{mmol}, 1.1$ equiv) was dissolved in $\mathrm{CH}_{2} \mathrm{Cl}_{2}(130 \mathrm{~mL})$, cooled to $0{ }^{\circ} \mathrm{C}$, and $\mathrm{BH}_{3} \cdot \mathrm{THF}(1 \mathrm{M}$ in THF, $26.0 \mathrm{~mL}, 26.0 \mathrm{mmol}, 1.0$ equiv) was added dropwise over a period of $10 \mathrm{~min}$. The suspension was stirred at $0{ }^{\circ} \mathrm{C}$ for $30 \mathrm{~min}$ before warming to $\mathrm{rt}$ and stirring for $1 \mathrm{~h}$. Continuous bubbling was observed, and the white solid slowly dissolved to give a clear solution. After cooling the solution to $-78^{\circ} \mathrm{C}$, cinnamaldehyde (11, $3.27 \mathrm{~mL}, 26.0 \mathrm{mmol}, 1.0$ equiv) in $\mathrm{CH}_{2} \mathrm{Cl}_{2}(70 \mathrm{~mL})$ and TBS ketene acetal $\left(\mathbf{9}, 8.56 \mathrm{~mL}, 31.2 \mathrm{mmol}, 1.2\right.$ equiv) in $\mathrm{CH}_{2} \mathrm{Cl}_{2}$ $(70 \mathrm{~mL})$ were successively added via syringe pump (2.5 $\mathrm{mL} / \mathrm{min}$ ). Stirring was continued for $10 \mathrm{~min}$ at $-78^{\circ} \mathrm{C}$ and $\mathrm{PB} \mathrm{pH}$ 
$7(30 \mathrm{~mL})$ was added at $-78{ }^{\circ} \mathrm{C}$. The mixture was diluted with $\mathrm{Et}_{2} \mathrm{O}(500 \mathrm{~mL})$, and the organic layer was washed with $\mathrm{PB} \mathrm{pH}$ 7/sat. aq. $\mathrm{NaCl}(4: 1,250 \mathrm{~mL})$, sat. aq. $\mathrm{NaHCO}_{3}(200 \mathrm{~mL})$, and sat. aq. $\mathrm{NaCl}(200 \mathrm{~mL})$ before drying over $\mathrm{Na}_{2} \mathrm{SO}_{4}$. Concentrating the organic phase under reduced pressure provided an oily residue which was directly dissolved in $\mathrm{EtOH} / \mathrm{H}_{2} \mathrm{O}(9: 1,57.2 \mathrm{~mL})$. After addition of $\mathrm{NaHSO}_{3}(2.70 \mathrm{~g}, 26.0 \mathrm{mmol}, 1.0$ equiv), the suspension was heated to $37^{\circ} \mathrm{C}$ for $3 \mathrm{~h}$ followed by filtration through Celite and rinsing of the filter cake with $\mathrm{Et}_{2} \mathrm{O}$. The filtrate was concentrated in vacuo, redissolved in $\mathrm{Et}_{2} \mathrm{O}(100 \mathrm{~mL})$ and filtered again through Celite. Rotary evaporation gave an oily residue that was purified via flash column chromatography (pentane $/ \mathrm{Et}_{2} \mathrm{O}=$ 185:15) to give an intractable diasteromeric mixture of (1S,E)-1[(4R)-4-\{[(tert-butyldimethylsilyl)oxy](methoxy)methyl\}-2,2dimethyl-1,3-dioxolan-4-yl]-3-phenylprop-2-en-1-ol (12, 7.08 g, $17.3 \mathrm{mmol}, 67 \%$ ) as a clear oil.

\section{Analytical Data of 12-1}

$R_{f}$ (pentane $\left./ \mathrm{Et}_{2} \mathrm{O}=9: 1\right)=0.24$. (UV, CAM). ${ }^{1} \mathrm{H}$ NMR $(400 \mathrm{MHz}$, $\left.\mathrm{CD}_{2} \mathrm{Cl}_{2}\right): \delta=7.42-7.38(\mathrm{~m}, 2 \mathrm{H}), 7.34-7.28(\mathrm{~m}, 2 \mathrm{H}), 7.25-7.19$ $(\mathrm{m}, 1 \mathrm{H}), 6.65(\mathrm{dd}, J=16.0,1.6 \mathrm{~Hz}, 1 \mathrm{H}), 6.41(\mathrm{dd}, J=16.0,5.4 \mathrm{~Hz}$, $1 \mathrm{H}), 4.80(\mathrm{~s}, 1 \mathrm{H}), 4.46(\mathrm{td}, J=6.0,1.7 \mathrm{~Hz}, 1 \mathrm{H}), 4.00(\mathrm{q}, J=9.3 \mathrm{~Hz}$, $2 \mathrm{H}), 3.44(\mathrm{~s}, 3 \mathrm{H}), 3.14(\mathrm{~d}, J=6.1 \mathrm{~Hz}, 1 \mathrm{H}), 1.43(\mathrm{~s}, 6 \mathrm{H}), 0.92(\mathrm{~s}, 9$ $\mathrm{H}), 0.17(\mathrm{~s}, 3 \mathrm{H}), 0.17(\mathrm{~s}, 3 \mathrm{H}) \mathrm{ppm} .{ }^{13} \mathrm{C}$ NMR $\left(101 \mathrm{MHz}, \mathrm{CD}_{2} \mathrm{Cl}_{2}\right)$ : $\delta=137.8,130.8,129.3,129.0,127.8,126.9,111.3,102.0,86.4$, 73.7, 67.8, 57.7, 27.1, 26.7, 26.1, 18.5, -4.1, -4.2 ppm. HRMS (EI): $\mathrm{m} / z$ calcd for $\mathrm{C}_{21} \mathrm{H}_{33} \mathrm{O}_{5} \mathrm{Si}^{+}\left[\mathrm{M}-\mathrm{CH}_{3}{ }^{-}\right]^{+}:$393.2097; found: 393.2095. IR (Diamond-ATR, neat): $v_{\max }=3504(\mathrm{vw}), 2955$, 2931,2897 (vw), 2858 (vw), 1741 (vw), 1496 (vw), 1472, 1463, 1449 (vw), 1380, 1370, 1252, 1210, 1063 (vs), 1005, 968, 939, 834 (vs), 778, 750, 693, $670 \mathrm{~cm}^{-1}$. [ $\left.\alpha\right]_{D}^{20}-8.00$ ( $c=1.99$, EtOAc).
(23) Selective Benzoylation Procedure for the Synthesis of Kweichowenol A (1)

Diol (17, $4.7 \mathrm{mg}, 15 \mu \mathrm{mol}, 1.0$ equiv) was dissolved in pyridine (0.15 mL), cooled to $-27{ }^{\circ} \mathrm{C}$, and $\mathrm{BzCl}(1.78 \mu \mathrm{L}, 15.4 \mu \mathrm{L}, 1.05$ equiv) in pyridine $(0.1 \mathrm{~mL})$ was added dropwise. The solution was allowed to warm to $-20^{\circ} \mathrm{C}$ over a period of $15 \mathrm{~min}$ and stirring was continued at the same temperature for $40 \mathrm{~min}$. Thereafter, $3 \%$ aq. $\mathrm{KHSO}_{4}(1 \mathrm{~mL})$ was added, and the mixture was diluted with EtOAc $(30 \mathrm{~mL})$. The organic layer was washed with $3 \%$ aq. $\mathrm{KHSO}_{4}(10 \mathrm{~mL})$, sat. aq. $\mathrm{NaCl}(10 \mathrm{~mL})$, dried over $\mathrm{Na}_{2} \mathrm{SO}_{4}$, and concentrated. Purification via flash column chromatography (pentane/EtOAc $=9: 1 \rightarrow 8: 1)$ afforded kweichowenol A (1, $4.3 \mathrm{mg}, 10 \mu \mathrm{mol}, 69 \%$ ) as a white solid.

Analytical Data of Synthetic Kweichowenol A (1) $R_{f}$ (pentane/EtOAC $=19: 1)=0.21 .(\mathrm{UV}, \mathrm{CAM}) .{ }^{1} \mathrm{H}$ NMR $\left(600 \mathrm{MHz}, \mathrm{C}_{6} \mathrm{D}_{6}\right)$ : $\delta=8.17-8.14(\mathrm{~m}, 2 \mathrm{H}), 8.10-8.08(\mathrm{~m}, 2 \mathrm{H}), 7.62-7.56(\mathrm{~m}, 2 \mathrm{H})$, 7.50-7.44 (m, $4 \mathrm{H}), 5.85-5.79(\mathrm{~m}, 2 \mathrm{H}), 5.79-5.78(\mathrm{~m}, 1 \mathrm{H}), 5.61$ (ddd, $J=8.6,2.5,1.4 \mathrm{~Hz}, 1 \mathrm{H}), 4.38(\mathrm{~d}, J=8.4 \mathrm{~Hz}, 1 \mathrm{H}), 4.33(\mathrm{~d}, J=$ $8.4 \mathrm{~Hz}, 1 \mathrm{H}), 4.28(\mathrm{~d}, J=8.5 \mathrm{~Hz}, 1 \mathrm{H}), 2.64(\mathrm{~s}, 1 \mathrm{H}), 1.46(\mathrm{~s}, 3 \mathrm{H})$, $1.32(\mathrm{~s}, 3 \mathrm{H}) \mathrm{ppm} .{ }^{13} \mathrm{C}$ NMR $\left(151 \mathrm{MHz}, \mathrm{C}_{6} \mathrm{D}_{6}\right): \delta=166.5,166.0$, 133.6, 133.5, 130.2, 130.0, 129.77, 129.76, 129.4, 128.7, 128.6, 127.5, 111.1, 85.6, 74.2, 73.8, 72.4, 64.5, 27.0, 26.2 ppm. HRMS (ESI): $\mathrm{m} / z$ calcd for $\mathrm{C}_{26} \mathrm{H}_{27} \mathrm{O}_{9}^{-}\left[\mathrm{M}+\mathrm{CH}_{3} \mathrm{COO}^{-}\right]^{-}: 483.1661$; found: 483.1665. IR (Diamond-ATR, neat): $v_{\max }=3588(\mathrm{vw}), 2920$, 2851 (vw), 2166, 1714, 1600 (vw), 1453, 1382 (vw), 1369, 1316, 1268 (vs), 1206, 1177, 1147 1111, 1089, 1064 (vs), 1023, 962, $881,863,798,780,701$ (vs), $668 \mathrm{~cm}^{-1} \cdot[\alpha]_{\mathrm{D}}{ }^{20}-168^{\circ}(c=0.538$, $\mathrm{CHCl}_{3}$ ).

(24) Nicolaou, K. C.; Chen, J. S. In Classics in Total Synthesis III.; WileyVCH: Weinheim, 2011. 